\title{
The association of plasma fibrinogen with clinicopathological features and prognosis in esophageal cancer patients
}

\author{
Fang-Teng Liu' ${ }^{1, *}$, Hui Gao ${ }^{1, *}$, Chang-Wen Wu ${ }^{2, *}$ and Zheng-Ming Zhu ${ }^{1}$ \\ ${ }^{1}$ Department of General Surgery, The Second Affiliated Hospital of Nanchang University, Nanchang 330000, Jiangxi Province, \\ P.R. China \\ ${ }^{2}$ Department of Urology, The Second Affiliated Hospital of Nanchang University, Nanchang 330000, Jiangxi Province, P.R. \\ China \\ "These authors have contributed equally to this work \\ Correspondence to: Zheng-ming Zhu, email: zzm8654@163.com \\ Keywords: plasma fibrinogen, esophageal cancer, prognosis, clinicopathological feature, biomarker \\ Received: May 07, $2017 \quad$ Accepted: August 04, $2017 \quad$ Published: October 10, 2017 \\ Copyright: Liu et al. This is an open-access article distributed under the terms of the Creative Commons Attribution License 3.0 \\ (CC BY 3.0), which permits unrestricted use, distribution, and reproduction in any medium, provided the original author and source \\ are credited.
}

\section{ABSTRACT}

Background: Numerous studies have shown that plasma fibrinogen was linked to esophageal cancer (EC) risk. However, the clinical significance of plasma fibrinogen in EC patients remain unclear and need to be further clarified.

Results: A total of $\mathbf{2 8 6 5}$ patients with EC from 11 published studies were included in this meta-analysis. The prognostic and clinical relevance of plasma fibrinogen were evaluated in EC patients. Statistical significance of the pooled hazard ratio (HR) was found for overall survival (OS), disease free survival (DFS) and recurrence-free survival (RFS) in EC. Subgroup analyses for OS were also performed to confirm the prognostic value of plasma fibrinogen. Additionally, the overall results indicated that elevated plasma fibrinogen was significantly associated with tumor invasion, lymph node metastasis (LNM) and clinical stage.

Materials and Methods: A comprehensive literature retrieval was performed in PubMed, Embase, Cochrane database, Web of science and Chinese National Knowledge Infrastructure (CNKI) and Wanfang databases to identify relevant studies published prior to April 15, 2017.

Conclusions: Elevated plasma fibrinogen could be served as a promising biomarker for predicting a poor prognosis and unfavorable clinicopathologic features for EC.

\section{INTRODUCTION}

Esophageal cancer (EC), as one of the most aggressive cancers, has been the fifth leading cause of cancer-related deaths in China, the eighth most common cancer worldwide [1,2]. There were two main subtypes, esophageal squamous-cell carcinoma (ESCC) and esophageal adenocarcinoma (EAC) [3]. Although the diagnosis and therapeutic method of EC have made much progress recently, most cases have been diagnosed initially at the advanced or metastatic disease stage, while the prognosis remained poor, especially for 5-year survival rate $[4,5]$. Therefore, prognostic molecular markers for $\mathrm{EC}$ are urgently necessary with great clinical significance.

Fibrinogen, as a pro-inflammatory protein commonly involved in the process of hemostasis, has played an important role in both inflammatory responses and tumor progression and metastasis [6-8]. Numerous studies have reported that fibrinogen level in plasma was upregulated in several types of cancers and related to cancer progression and prognosis [9-14]. The roles of plasma fibrinogen on survival outcomes of EC also have been recognized, however, there were some conflicting findings. For example, Wakatsuki [15] found that plasma 
fibrinogen was associated with not only advanced clinicopathological factors but also the overall survival and relapse-free survival in EC patients. Wang and Takeuchi $[16,17]$ demonstrated that plasma fibrinogen was a valuable predictor for disease progression and prognosis in ESCC. However, Li et al. [18] reported that there was no significant association between preoperative plasma fibrinogen level and prognosis of ESCC. Therefore, the prognosis value of plasma fibrinogen in EC was still unclear without methodical analysis.

The aim of this work was to provide a synthetic analysis and systematic review for the role of fibrinogen in $\mathrm{EC}$, and to clarify the prognostic significance and clinical relevance of plasma fibrinogen in EC patients.

\section{RESULTS}

\section{Study characteristics}

According to the inclusion and exclusion criteria mentioned above, finally, a total of 11 studies [15-25] were considered eligible for this present meta-analysis. All studies reported prognostic value of plasma fibrinogen in EC patients. The detailed selection steps were presented (Figure 1).

There were totally $2865 \mathrm{EC}$ cases involved in the meta-analysis, the mean sample size was 260.5 with a minimum sample size of 68 and a maximum number of 1512. Among those included studies, 4 came from P.R. China, 6 from Japan, 1 from Austria. There were 8 studies for OS, 4 studies for DFS, 2 studies for RFS, 1 study for CSS, 1 study for LRFS and 1 study for DMFS. All recruited patients had been pathologically or histologically confirmed as EC.

Plasma fibrinogen was determined in 4 studies with a functional method based on the Clauss assay, 4 studies with automatic coagulation analyzer, 1 studies with immunoassay enzyme-linked immunosorbent assay kit, in the rest of the 2 studies, the assay was not provided. Differences in the cut-off value for determining high plasma fibrinogen were observed among the included studies. The main information of the 11 studies included in our meta-analysis was summarized (Table 1).

\section{Relationship between plasma fibrinogen and EC prognosis/OS in EC}

A total of 8 studies, including 2631 EC cases, reported the OS corresponding to the level of plasma fibrinogen. There was no significant heterogeneity among studies $\left(\mathrm{I}^{2}=0.0 \%, \mathrm{P}_{\mathrm{h}}=0.455\right)$, thus the fixed-effects model was adopted to evaluate the pooled HRs with corresponding 95\% CIs. The overall results demonstrated that EC patients with increased plasma fibrinogen showed a significantly poor OS compared to those with lower plasma fibrinogen (HR:1.27, 95\% CI:1.14-1.40, $p<0.001$ ) (Figure 2).

Further, we performed subgroup analyses for OS by the pathology subtype, country, cut-off value, sample size and analysis type. Statistically significant pooled HR values $>1$ were also consistently calculated in those subgroup meta-analyses (Table 2, those figures are presented in the Supplementary Materials).

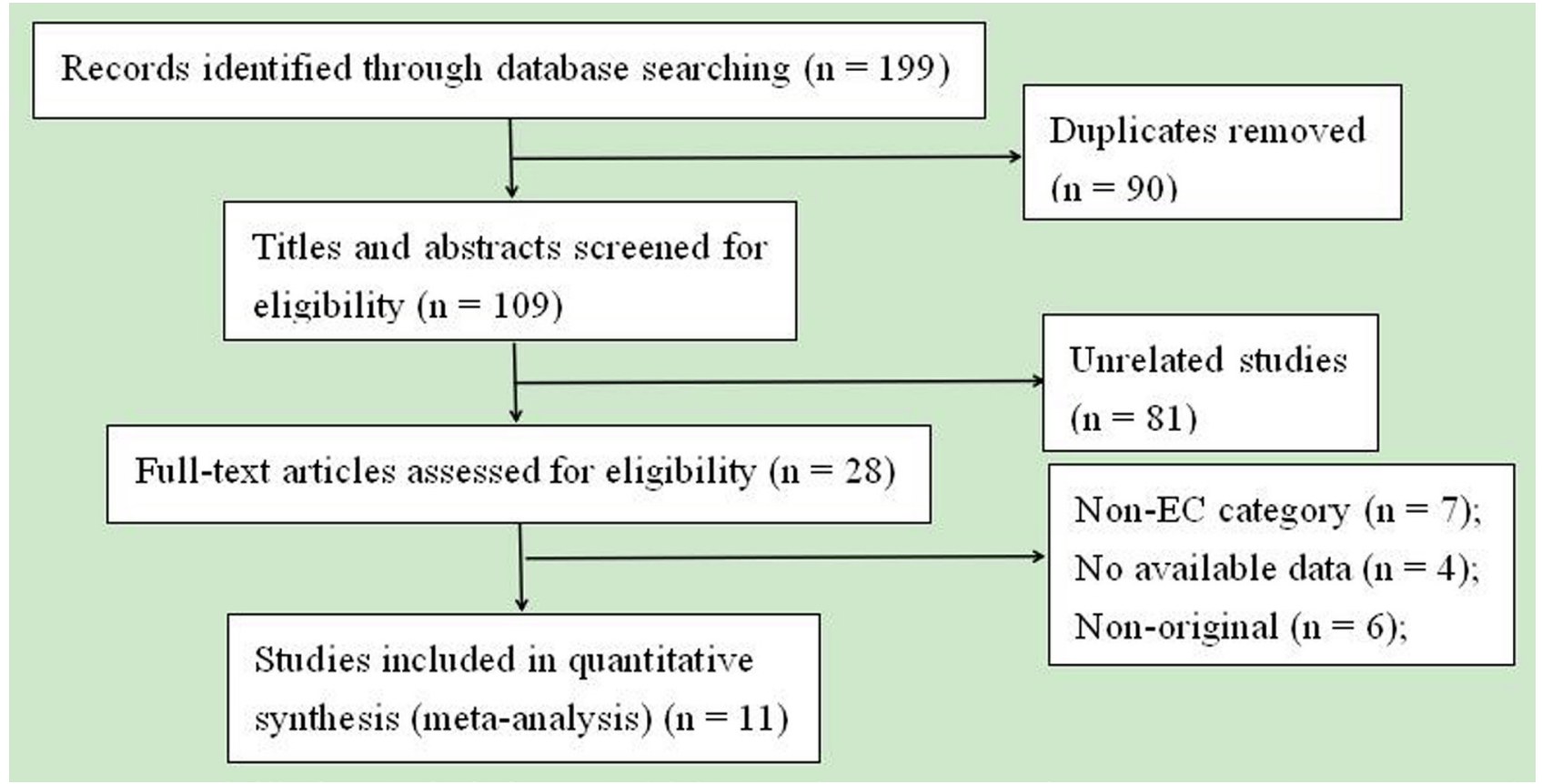

Figure 1: The flow diagram of the included studies. 
Table 1: Main characteristics of all included studies

\begin{tabular}{|c|c|c|c|c|c|c|c|c|c|c|c|}
\hline Study (Year) & Country & $\begin{array}{c}\text { No. of } \\
\text { patients }\end{array}$ & $\begin{array}{l}\text { Pathology } \\
\text { subtype }\end{array}$ & $\begin{array}{l}\text { Clinical } \\
\text { stage }\end{array}$ & Treatments & $\begin{array}{l}\text { Included } \\
\text { period }\end{array}$ & $\begin{array}{c}\text { Age median } \\
\text { (range) (year) }\end{array}$ & $\begin{array}{c}\text { Gender } \\
(\mathbf{M} / \mathbf{F})\end{array}$ & $\begin{array}{r}\text { Cut-off } \\
\text { (mg/dL) }\end{array}$ & Follow-up & Prognosis \\
\hline $\begin{array}{c}\text { Wakatsuki K, } 2017 \\
{[15]}\end{array}$ & Japan & 100 & ESCC & I-IV & $\begin{array}{l}\text { Surgery+ adjuvant } \\
\text { chemotherapy (Only for } \\
\text { patients with LNM) }\end{array}$ & $1995-2006$ & $\begin{array}{c}50: \geq 62 \text { years; } \\
50:<62 \text { years }\end{array}$ & $79 / 21$ & 400 & $\begin{array}{l}\text { above } 100 \\
\text { months }\end{array}$ & OS, RFS \\
\hline $\begin{array}{c}\text { Kijima T, } 2017 \\
{[19]}\end{array}$ & Japan & 98 & ESCC & III/IV & Radio/Chemotherapy & 2011-2014 & $64.9(46-86)$ & $86 / 12$ & 400 & $\begin{array}{l}\text { median: } 15.4 \\
\text { months }\end{array}$ & OS \\
\hline $\begin{array}{l}\text { Suzuki T, } 2017 \\
{[22]}\end{array}$ & Japan & 82 & ESCC & I-IV & Surgery or ESD & 2009-2014 & $67(34-87)$ & $66 / 16$ & 321 & $\begin{array}{l}\text { median: } 28.5 \\
\text { months }\end{array}$ & CSS \\
\hline $\begin{array}{c}\text { Zhang SS, } 2016 \\
{[20]}\end{array}$ & China & 1512 & $\begin{array}{c}\text { ESCC+EA+ } \\
\text { Others }\end{array}$ & I-IV & $\begin{array}{l}\text { Surgery or Radio/ } \\
\text { Chemotherapy }\end{array}$ & $2000-2008$ & $\begin{array}{l}730:>58 \text { years; } \\
782: \leq 58 \text { years }\end{array}$ & $1144 / 368$ & 400 & (1-140) months & OS, DFS \\
\hline $\begin{array}{c}\text { Arigami T, } 2015 \\
{[21]}\end{array}$ & Japan & 238 & ESCC & I-III & Surgery & $1998-2012$ & $65(37-87)$ & $210 / 28$ & 400 & $\begin{array}{l}\text { median: } 26 \\
\text { months }\end{array}$ & OS \\
\hline $\begin{array}{l}\text { Ilhan-Mutlu A, } \\
2015 \text { [23] }\end{array}$ & Austria & 84 & $\mathrm{ESCC}+\mathrm{EA}$ & I-IV & $\begin{array}{l}\text { Neo-adjuvant } \\
\text { therapy+Surgery }\end{array}$ & 1996-2011 & mean $(63 \pm 9)$ & $70 / 14$ & 439.5 & $<5$ years & DFS \\
\hline $\begin{array}{c}\text { Wang J, } 2015 \\
{[17]}\end{array}$ & China & 119 & ESCC & I-III & $\begin{array}{l}\text { Surgery+ Adjuvant } \\
\text { treatment (only } 48 \text { with } \\
\text { Radio/Chemotherapy) }\end{array}$ & 2008 & $60(42-78)$ & $95 / 24$ & 400 & $\begin{array}{l}\text { above } 60 \\
\text { months }\end{array}$ & OS, DFS \\
\hline $\begin{array}{c}\text { Zhang D, } 2015 \\
{[24]}\end{array}$ & China & 255 & ESCC & I-IV & $\begin{array}{l}\text { Surgery+ Radio/ } \\
\text { Chemotherapy }\end{array}$ & 2006-2009 & $57(36-81)$ & $232 / 23$ & 400 & $\begin{array}{l}\text { above } 60 \\
\text { months }\end{array}$ & $\begin{array}{l}\text { OS, RFS, } \\
\text { LRFS, DMFS }\end{array}$ \\
\hline $\begin{array}{c}\mathrm{Li} \mathrm{XH}, 2015 \\
{[18]}\end{array}$ & China & 204 & ESCC & I-IV & $\begin{array}{c}\text { Surgery+ Radio/ } \\
\text { Chemotherapy (Only for } \\
\text { some patients) }\end{array}$ & $2007-2008$ & $59(36-79)$ & $145 / 59$ & 400 & NA & OS \\
\hline $\begin{array}{c}\text { Matsuda S, } 2014 \\
{[25]}\end{array}$ & Japan & 68 & ESCC & I-III & $\begin{array}{l}\text { Radio/Chemotherapy/Neo- } \\
\text { adjuvant therapy+Surgery }\end{array}$ & 2001-2010 & $\begin{array}{l}(\text { mean } \pm \text { SD }) \\
(61.8 \pm 8.11)\end{array}$ & $61 / 7$ & 350 & (1-100) months & DFS \\
\hline $\begin{array}{c}\text { Takeuchi H, } 2007 \\
{[16]}\end{array}$ & Japan & 105 & ESCC & I-IV & $\begin{array}{l}\text { Surgery/EMR+ Radio/ } \\
\text { Chemotherapy (Only for } \\
\text { some patients) }\end{array}$ & $1995-2005$ & $68(45-88)$ & $90 / 15$ & 350 & $\begin{array}{l}\text { median: } 37 \\
\text { months }\end{array}$ & OS \\
\hline
\end{tabular}

ESCC: esophageal squamous cell carcinoma; EA: esophageal adenocarcinoma; OS: overall survival; DFS: disease-free survival; RFS: relapse-free survival; CSS: cause-specific survival; LRFS: locoregional relapse-free survival; DMFS: distant metastasis free survival; LNM: lymph node metastasis; ESD:endoscopic submucosal dissection; EMR:endoscopic mucosal resection

Study

ID

\author{
$\%$ \\ $\mathrm{HR}(95 \% \mathrm{Cl}) \quad$ Weight
}

Wakatsuki K,2017

Kijima T,2017

Zhang SS,2016

Arigami T,2015

Wang J,2015

Zhang D,2015

$\mathrm{Li}$ XH,2015

Takeuchi H,2007

Overall (I-squared $=0.0 \%, p=0.455$ )

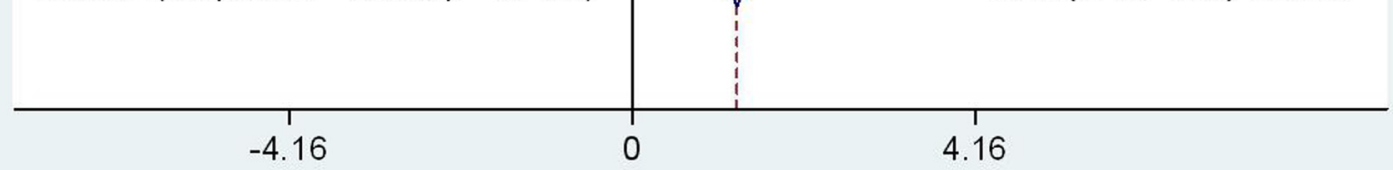

Figure 2: Forest plot of HR for the relationship between plasma fibrinogen and OS in EC. 
Table 2: Summary of the meta-analysis results of pooled HRs of OS of EC patients with elevated plasma fibrinogen

\begin{tabular}{|c|c|c|c|c|c|c|}
\hline \multirow{2}{*}{ Analysis } & \multirow{2}{*}{ No. of studies } & \multirow{2}{*}{$\begin{array}{c}\text { No. of } \\
\text { patients }\end{array}$} & \multirow{2}{*}{$\begin{array}{c}\text { Pooled HR } \\
(95 \% \text { CI })\end{array}$} & \multirow{2}{*}{$p$-value } & \multicolumn{2}{|c|}{ Heterogeneity } \\
\hline & & & & & $I^{2}(\%)$ & $\mathbf{P}_{\mathrm{h}}$ \\
\hline [1] OS & 8 & 2631 & $1.27(1.14-1.40)$ & $<0.001$ & 0.0 & 0.455 \\
\hline \multicolumn{7}{|c|}{ [2] Pathology subtype } \\
\hline ESCC & 7 & 1119 & $1.36(1.16-1.55)$ & $<0.001$ & 0.0 & 0.499 \\
\hline Mixed & 1 & 1512 & $1.20(1.04-1.38)$ & 0.012 & - & - \\
\hline \multicolumn{7}{|l|}{ [3] Country } \\
\hline China & 4 & 2090 & $1.23(1.08-1.39)$ & $<0.001$ & 24.3 & 0.265 \\
\hline Japan & 4 & 541 & $1.34(1.11-1.57)$ & $<0.001$ & 0.0 & 0.526 \\
\hline \multicolumn{7}{|l|}{ [4] Cut-off value } \\
\hline $400 \mathrm{mg} / \mathrm{dL}$ & 7 & 2526 & $1.27(1.14-1.39)$ & $<0.001$ & 10.2 & 0.351 \\
\hline $350 \mathrm{mg} / \mathrm{dL}$ & 1 & 105 & $1.40(1.18-3.15)$ & 0.006 & - & - \\
\hline \multicolumn{7}{|l|}{ [5] Sample size } \\
\hline$\geq 200$ & 4 & 2209 & $1.24(1.11-1.37)$ & $<0.001$ & 0.0 & 0.618 \\
\hline$<200$ & 4 & 422 & $1.77(1.22-2.33)$ & $<0.001$ & 0.0 & 0.656 \\
\hline \multicolumn{7}{|l|}{ [6] Analysis type } \\
\hline Multivariate & 3 & 1867 & $1.24(1.07-1.40)$ & $<0.001$ & 48.8 & 0.142 \\
\hline Non-multivariate & 5 & 764 & $1.31(1.11-1.52)$ & $<0.001$ & 0.0 & 0.647 \\
\hline
\end{tabular}

\section{Plasma fibrinogen and DFS in EC}

A total of 4 studies, comprising 1783 EC patients, explored the relationship between plasma fibrinogen and DFS. No significant heterogeneity was observed among studies $\left(\mathrm{I}^{2}=0.0 \% ; \mathrm{P}_{\mathrm{h}}=0.420\right)$, the fixed-effects model was applied. The pooled results showed DFS was significantly worse in EC patients with high plasma fibrinogen $(\mathrm{HR}=1.21 ; 95 \% \mathrm{CI}=1.06-1.37 ; p<0.001)$ (Figure 3).

\section{Plasma fibrinogen and RFS in EC}

Only two studies, with a total of 355 patients, provided available information for RFS analysis. The fixed-effects model was applied since there was no significant heterogeneity across-studies $\left(\mathrm{I}^{2}=0.0 \% ; \mathrm{P}_{\mathrm{h}}\right.$ $=0.861)$. As shown in Figure 4, EC patients with higher plasma fibrinogen level had a worse RFS compared with those with lower plasma fibrinogen $(\mathrm{HR}=1.96 ; 95 \% \mathrm{CI}=$ $1.31-2.61 ; p<0.001)$.

\section{Association between plasma fibrinogen and clinical parameters in EC}

Regarding the clinical significance of plasma fibrinogen in EC patients, the pooled results indicated that elevated plasma fibrinogen was significantly associated with the depth of tumor invasion $(\mathrm{OR}=$ 3.26, 95\% CI: 1.75-6.07), lymph node metastasis (OR $=1.79,95 \% \mathrm{CI}: 1.48-2.16)$ and clinical stages $(\mathrm{OR}=$ 3.23 , 95\% CI: 2.02-5.16). But no significant correlation was observed between plasma fibrinogen with gender or tumor differentiation. The detailed results for plasma fibrinogen and clinicopathological parameters were provided (Table 3, those figures are presented in the Supplementary Materials).

\section{Publication bias}

For the meta-analysis of the association between plasma fibrinogen and OS, Begg's funnel plot was provided (Figure 5). The result from Begg's test showed that there was no significant publication bias acrossstudies (for Begg's test: $z=1.61$ (continuity corrected); $\operatorname{Pr}>|z|=0.108$ (continuity corrected)). However, the result from Egger's test showed a potential publication bias existed $(\mathrm{P}>|\mathrm{t}|=0.028,95 \% \mathrm{CI}: 0.258-3.178)$, then the "trim and fill method" was applied to replace four missing studies (Figure 6). After correction, the adjusted pooled HR was 1.236 (95\% CI: 1.127- 1.355, $p<0.001)$.

\section{Sensitivity analysis}

Sensitivity analysis was conducted to assess the effect of each single study on OS. It showed that the 
Study

ID

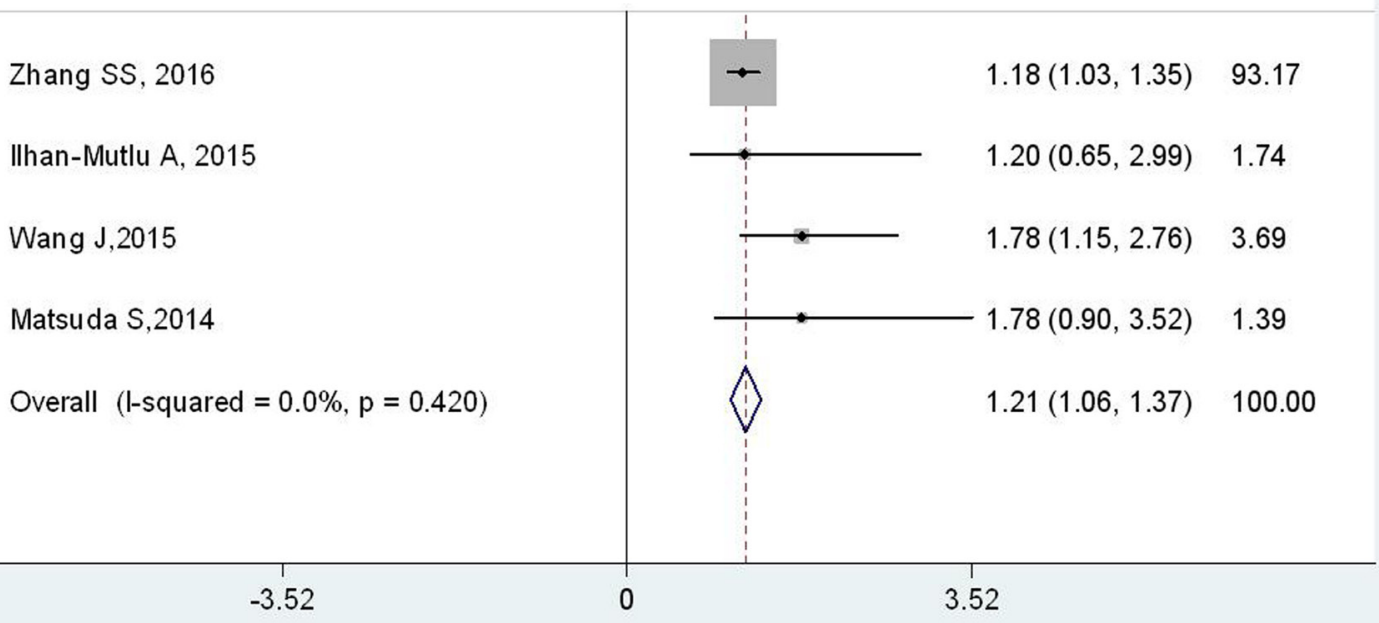

Figure 3: Forest plot of HR for the relationship between plasma fibrinogen and DFS.

Study

ID

Wakatsuki K,2017

Zhang D, 2015

Overall $($ l-squared $=0.0 \%, p=0.861)$
$\%$

HR $(95 \% \mathrm{Cl}) \quad$ Weight

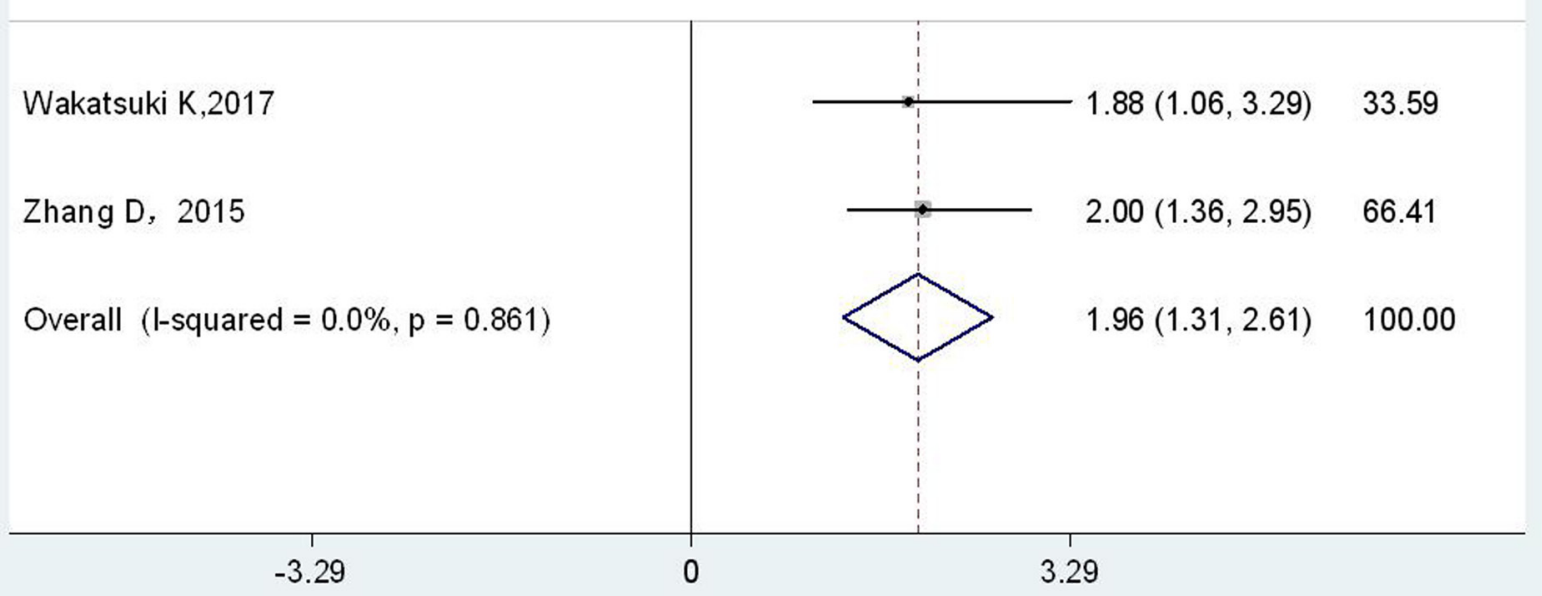

Figure 4: Forest plot of HR for the relationship between plasma fibrinogen and RFS. 
Table 3: Meta-analysis of the association between elevated plasma fibrinogen and clinicopathologic features in EC patients

\begin{tabular}{|c|c|c|c|c|c|c|c|}
\hline \multirow{2}{*}{$\begin{array}{l}\text { Clinicopathologic } \\
\text { features }\end{array}$} & \multirow{2}{*}{ Studies(n) } & \multirow{2}{*}{ No. of patients } & \multirow{2}{*}{ OR $(95 \%$ CI $)$} & \multirow{2}{*}{$p$-value } & \multicolumn{3}{|c|}{ Heterogeneity } \\
\hline & & & & & $I^{2}(\%)$ & $P_{h}$ & Model \\
\hline $\begin{array}{l}\text { Gender } \\
\text { (Male vs. Female) }\end{array}$ & 6 & 2136 & $1.53(0.83-2.82)$ & 0.17 & 55 & 0.05 & Random \\
\hline $\begin{array}{l}\text { Tumor invasion } \\
\text { (T3-T4 vs.T1-T2) }\end{array}$ & 6 & 2136 & $3.26(1.75-6.07)$ & 0.0002 & 78 & 0.0004 & Random \\
\hline $\begin{array}{l}\text { Tumor differentiation } \\
\text { (G2-G3 vs. G1) }\end{array}$ & 4 & 1986 & $1.00(0.81-1.24)$ & 0.99 & 0 & 0.77 & Fixed \\
\hline $\begin{array}{l}\text { Lymph node metastasis } \\
\text { (Yes vs. No) }\end{array}$ & 6 & 2136 & $1.79(1.48-2.16)$ & $<0.00001$ & 14 & 0.33 & Fixed \\
\hline $\begin{array}{l}\text { TNM stage } \\
\text { (III-IV vs. I-II) }\end{array}$ & 4 & 369 & $3.23(2.02-5.16)$ & $<0.00001$ & 0 & 0.46 & Fixed \\
\hline
\end{tabular}

combined result was not significantly altered after the exclusion of any studies (Figure 7).

\section{DISCUSSION}

A number of studies have reported various results relating hyperfibrinogenemia to EC risk of prognosis and clinical relevance. However, up to now, few meta-analysis has been performed to synthetically assess the clinical and prognostic value of plasma fibrinogen in EC patients.

In our current study, a total of 11 studies was combined to validate prognostic value of plasma fibrinogen in EC. The synthesis analysis showed that hyperfibrinogenemia was associated with clinical progression and worse survival in EC patients. The patients with higher plasma fibrinogen showed a shorter

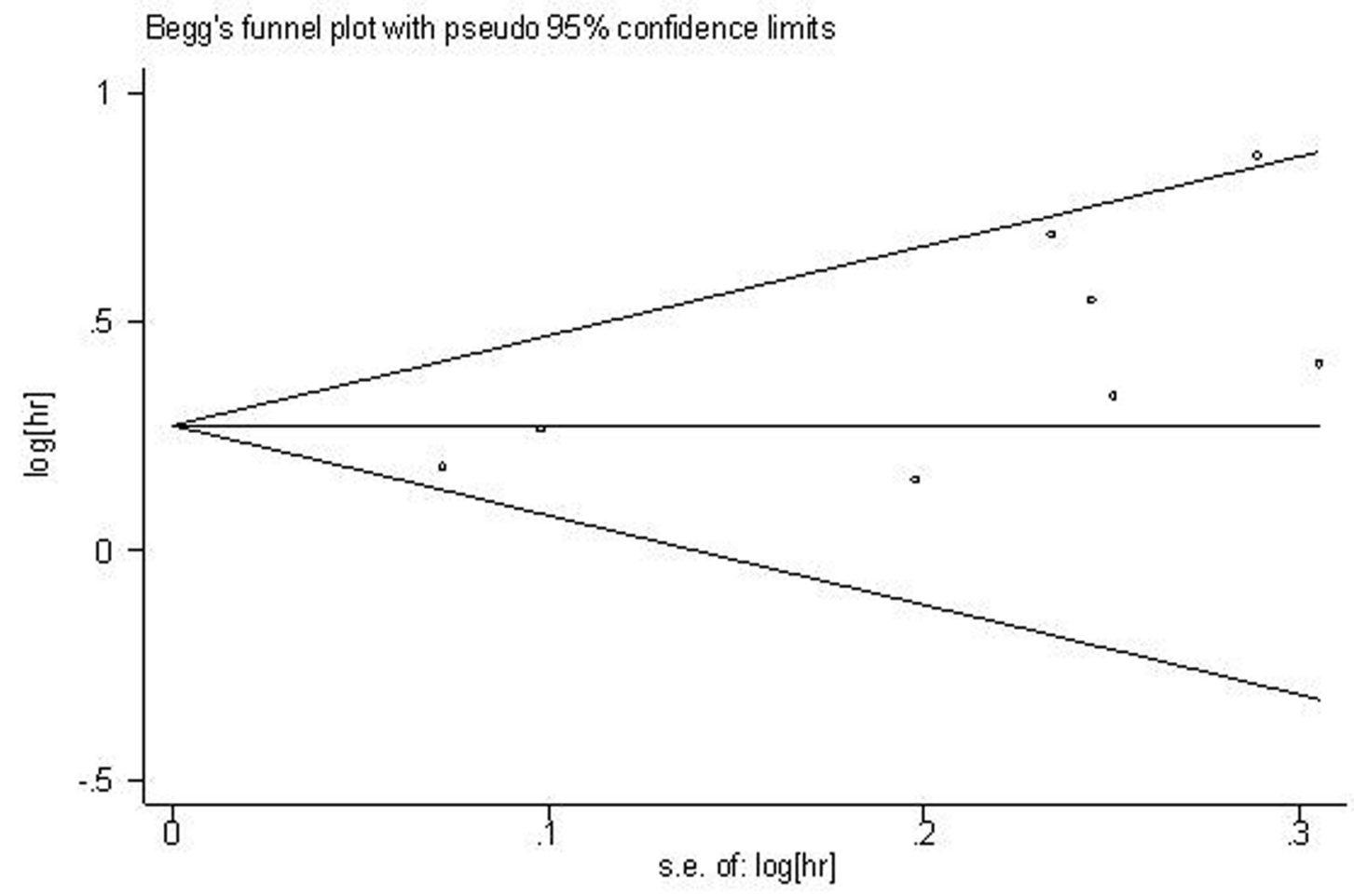

Figure 5: Funnel plot analysis of potential publication bias for OS. 
Filled funnel plot with pseudo $95 \%$ confidence limits

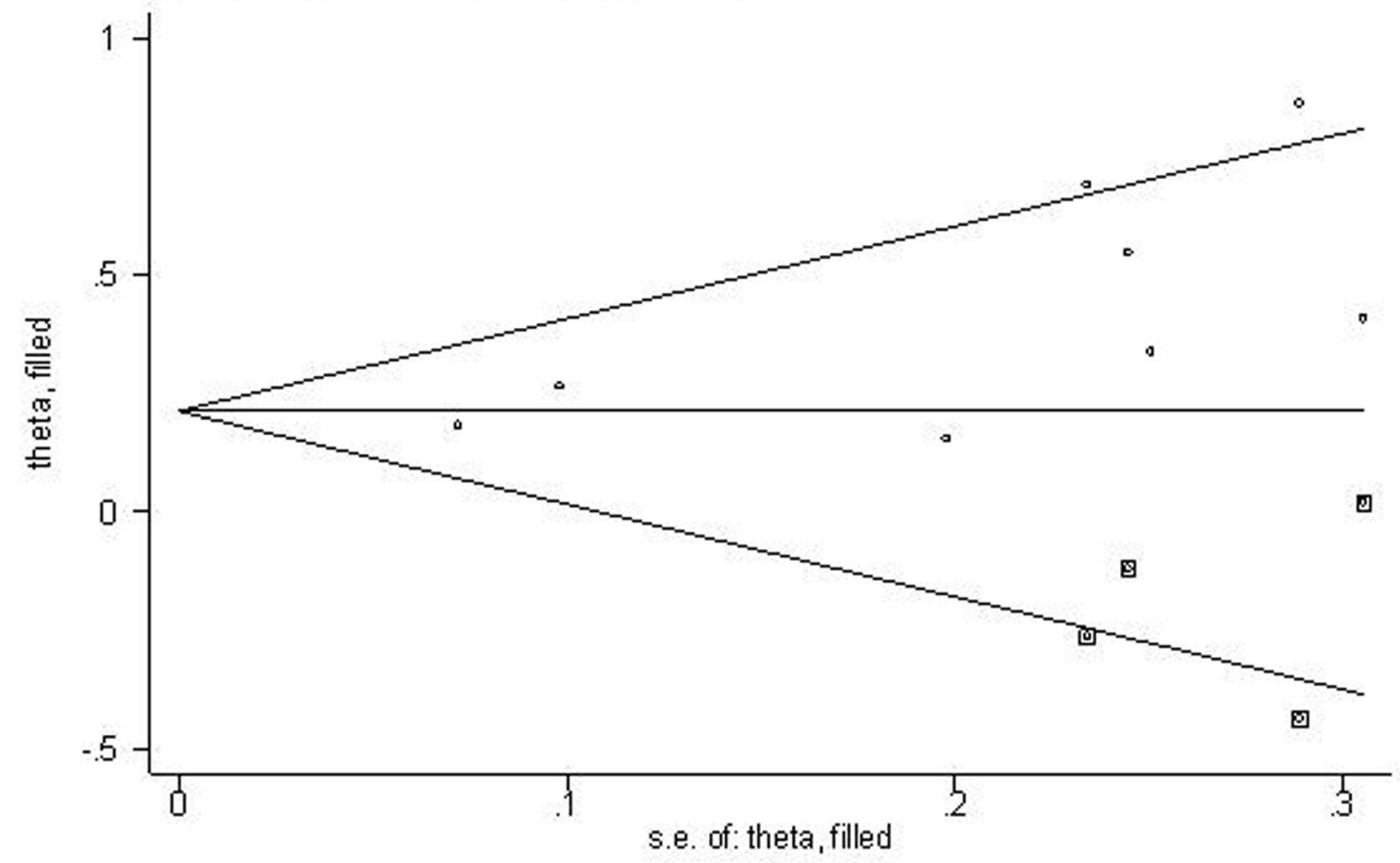

Figure 6: Filled funnel plot of meta-analysis using "trim-and-fill" method. "०" indicates observed studies; "ฉ" indicates missed studies.

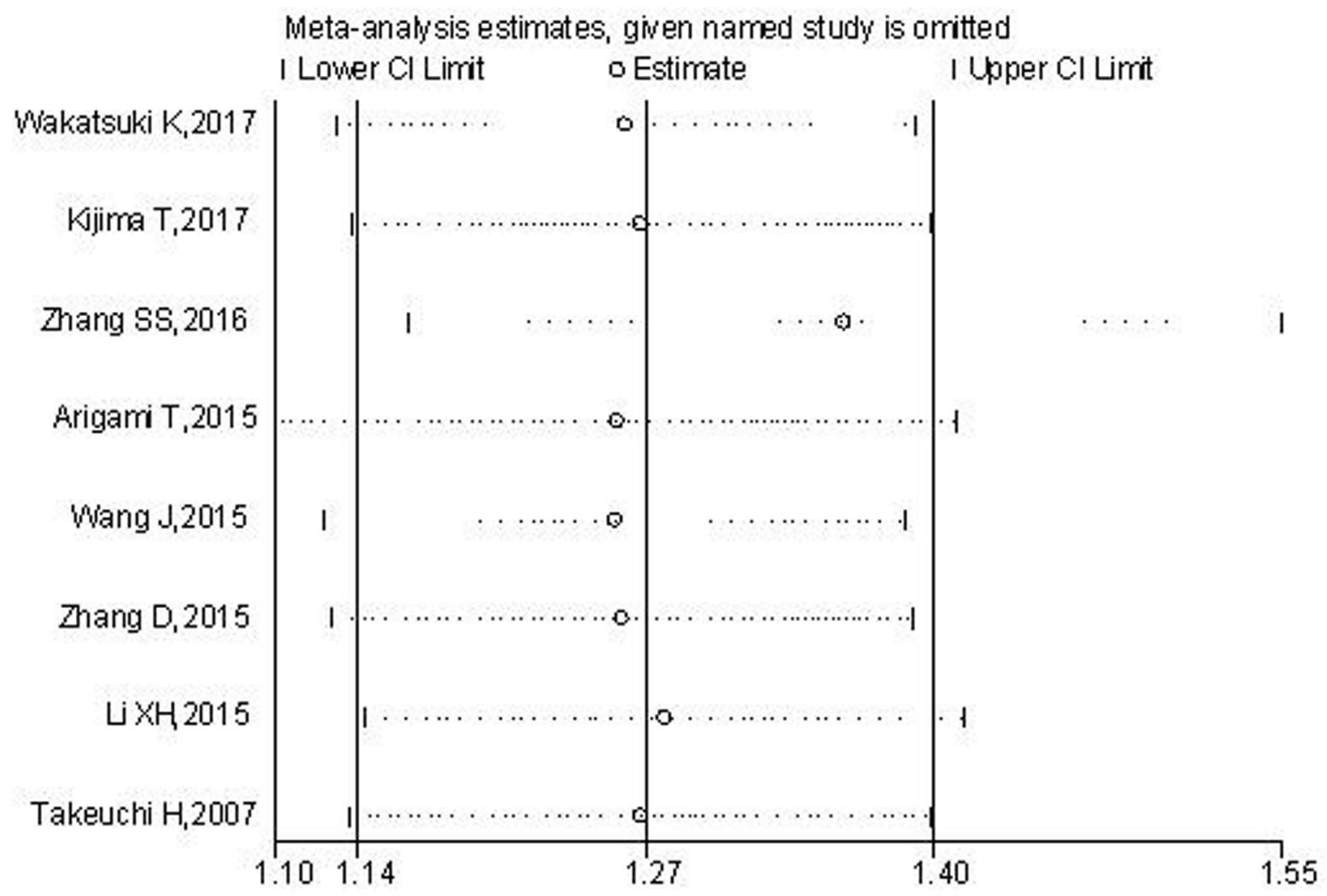

Figure 7: Sensitivity analysis of the pooled HRs of plasma fibrinogen and OS in EC. 
OS, poorer DFS and worse RFS when compared with those with lower expression level. Subgroup analyses for OS were also conducted to confirm the prognostic significance of plasma fibrinogen in EC. Furthermore, we explored the correlation between plasma fibrinogen level and some clinicopathological characteristics. EC patients with elevated plasma fibrinogen level were more likely to be with deeper tumor invasion, positive lymph node metastasis and advanced tumor stages. But there was no significant correlation between plasma fibrinogen with gender or tumor differentiation. Taken together, elevated plasma fibrinogen was associated with tumor progression and poor survival in patients with $\mathrm{EC}$, and it may serve as a valuable predictive factor for EC clinicopathology and prognosis.

The value in prognostic evaluation of plasma fibrinogen could be interpreted by its biological mechanism in EC patients from the important association between hemostatic factors and cancer progression. Inflammatory response has been believed to participate in the tumor progression, it could cause the elevated levels of various inflammatory cytokines [26-28]. Fibrinogen was a P-globulin, belong to pro-inflammatory protein. Fibrinogen participated in the formation of extracellular matrix and could be endogenously synthesized by cancer cells in addition to liver cells [29-31]. Fibrinogen played a key role in the development of tumor. It could regulate the growth of cancer cells by binding to the growth factors, such as vascular endothelial growth factor (VEGF) and platelet-derived growth factor (PDGF) [30-32]. Moreover, elevated fibrinogen could enhance the cell migration and invasion by induced epithelial-mesenchymal transition (EMT) via regulating the expression level of vimentin and Ecadherin [33]. It was also demonstrated that fibrinogen played an important role in the oncogenesis and development of tumor by aggravating cell proliferation, inhibiting apoptosis and stimulating angiogenesis and hematogenous metastasis [30, 31, 34-36]. The fibrinogen would also be affected by the chemotherapy and radiotherapy, through the trigger of inflammatory response and immune response.

Our meta-analysis was the first study to systematically investigate the clinical and prognostic value of plasma fibrinogen level in EC. The elevated level of plasma fibrinogen could predict poorer pathological features and was a significant risk factor affecting survival in $\mathrm{EC}$ patients.

However, several limitations of this study need to be acknowledged. Firstly, the number of included studies was relatively small and total sample size should be enlarged. Secondly, the cut-off value applied was varied in studies and the detection methods for plasma fibrinogen were not identical. Thirdly, most of patients enrolled came from Asia countries, and only one study included was from western country, this might limit the applicability of our findings for other ethnic groups. Fourthly, publication bias may exist, despite no significant publication bias was observed based on the trim and fill method, as well as stable results shown in sensitivity analysis. Finally, other factors might also play roles in EC prognosis, such as clinical stage and treatment.

In conclusion, our study provided a strong evidence that elevated plasma fibrinogen was closely associated with unfavorable prognosis and aggressive clinical features in patients with EC. Certainly, well-designed clinical researches on larger sample and other ethnic groups are needed to further validate of our study.

\section{MATERIALS AND METHODS}

\section{Search strategy}

We performed a comprehensive literature retrieval for published original articles in a number of online database: PubMed, Embase, Cochrane databases, Web of science and Chinese National Knowledge Infrastructure (CNKI) and Wanfang database. The retrieval was updated until April 15, 2017.

Retrieval was performed with following key search items: fibrinogen (e.g., "plasma fibrinogen"), esophageal cancer (e.g., "oesophageal cancer", "esophageal carcinoma", "EC", "esophageal squamous cell carcinoma", "ESCC", "esophageal adenocarcinoma") and prognosis (e.g., "prognostic", "survival", "outcome", "recurrence"). In addition, references of relevant publications were manually reviewed for potential eligible studies.

\section{Selection criteria and definitions}

The eligible articles were included only if they met the following criteria: (1) Clinical study investigated the prognostic effect of plasma fibrinogen on esophageal cancer; (2) the patients were divided into two groups according the level of plasma fibrinogen; (3) the hazard ratios with corresponding $95 \%$ CIs for prognosis were provided or could be manually calculated; (4) articles were published in English or Chinese.

Articles with the following criteria were excluded: (1) Reviews and non-original articles; (2) studies referred other kinds of human cancers; (3) studies lacking sufficient data to collect HRs with $95 \%$ CIs.

\section{Data extraction and study quality}

The data and information were extracted from those included studies independently by two investigators $(\mathrm{GH}$ and LFT), including: the name of first author, publication year, country, sample size, pathology subtype, clinical stage, recruitment period, age of patients, gender ratio, cut-off value, follow-up time, hazard ratio (HR) and 
corresponding $95 \%$ confidence interval (CI) for prognosis and relevant clinicopathological data.

If a study provided the results of both multivariate outcome and univariate outcome, we chose the former. If a study only provided Kaplan-Meier survival curves, then we extracted survival data from that via Engauge Digitizer V4.1. The relevant clinicopathologic characteristics were extracted directly from the original articles.

For quality assessment, the Newcastle-Ottawa Scale (NOS) was applied to assess the quality of studies. The NOS score was ranged from 0 to 9 . Studies with NOS score $\geq 6$ was graded as high quality. The quality of all including studies in this meta-analysis was varied from 6 to 9 , with a mean value of 6.5 .

\section{Statistical analysis}

The pooled HR and its corresponding 95\% CI for prognosis were calculated with Stata SE12.0. The combined ORs and its corresponding 95\% CI for clinical parameters were calculated by RevMan5.3 software.

Statistical heterogeneity among studies was assessed with $I^{2}$ test and Q statistic test, the fixed-effect model was applied when no obvious heterogeneity was observed among studies, otherwise, the random effects model was applied to calculate parameters when there was significant heterogeneity across studies $\left(\mathrm{I}^{2}>50 \%\right.$ or $\mathrm{P}_{\mathrm{h}}<0.05$ suggested significant heterogeneity).

Funnel plots and Begg's test/Egger's test were involved to search the potential publication bias. The sensitivity analysis was also performed to test the reliability of the combined results. A $p$ value less than 0.05 was considered statistically significant.

\section{ACKNOWLEDGMENTS AND FUNDING}

We thank for the financial support of National Natural Science Foundation of China (No.81560389).

\section{CONFLICTS OF INTEREST}

The authors declared no conflicts of interest.

\section{REFERENCES}

1. Torre LA, Bray F, Siegel RL, Ferlay J, Lortet-Tieulent J, Jemal A. Global cancer statistics, 2012. CA Cancer J Clin. 2015; 65:87-108.

2. Jemal A, Siegel R, Ward E, Hao Y, Xu J, Thun MJ. Cancer statistics, 2009. CA Cancer J Clin. 2009; 59:225-249.

3. Napier KJ, Scheerer M, Misra S. Esophageal cancer: a review of epidemiology, pathogenesis, staging workup and treatment modalities. World J Gastrointest Oncol. 2014; 6:112-120
4. Xu YW, Peng YH, Chen B, Wu ZY, Wu JY, Shen JH, Zheng CP, Wang SH, Guo HP, Li EM, Xu LY. Autoantibodies as potential biomarkers for the early detection of esophageal squamous cell carcinoma. Am J Gastroenterol. 2014; 109:36-45.

5. Palladino-Davis AG, Mendez BM, Fisichella PM, Davis CS. Dietary habits and esophageal cancer. Dis Esophagus. 2015; 28:59-67.

6. Ueki R, Liu L, Kashiwagi S, Kaneki M, Khan MA, Hirose M, Tompkins RG, Martyn JA, Yasuhara S. Role of elevated fibrinogen in burn-induced mitochondrial dysfunction: protective effects of glycyrrhizin. Shock. 2016; 46:382-389.

7. Luo Y, Kim HS, Kim M, Lee M, Song YS. Elevated plasma fibrinogen levels and prognosis of epithelial ovarian cancer: a cohort study and meta-analysis. J Gynecol Oncol. 2017; 28:e36.

8. Zeng Q, Xue N, Dai D, Xing S, He X, Li S, Du Y, Huang C, Li L, Liu W. A nomogram based on inflammatory factors C-reactive protein and fibrinogen to predict the prognostic value in patients with resected non-small cell lung cancer. J Cancer. 2017; 8:744-753.

9. Sun ZQ, Han XN, Wang HJ, Tang Y, Zhao ZL, Qu YL, $\mathrm{Xu}$ RW, Liu YY, Yu XB. Prognostic significance of preoperative fibrinogen in patients with colon cancer. World J Gastroenterol. 2014; 20:8583-8591.

10. Ma C, Zhou Y, Zhou S, Zhao K, Lu B, Sun E. Preoperative peripheral plasma fibrinogen level is an independent prognostic marker in penile cancer. Oncotarget. 2017; 8:12355-12363. https://doi.org/10.18632/oncotarget.12563.

11. Lan M, Chen C, Huang Y, Mao M, Han F, Liao J, Deng M, Duan Z, Zheng L, Wu S, Lu T, Jian Y. Elevated plasma fibrinogen level shows superior prognostic value than Epstein-Barr virus DNA load for stage IVA/B nasopharyngeal carcinoma patients in the intensitymodulated radiotherapy era. Oncotarget. 2016; 7:4624246252. https://doi.org/10.18632/oncotarget.10083.

12. Jagadesham VP, Lagarde SM, Immanuel A, Griffin SM. Systemic inflammatory markers and outcome in patients with locally advanced adenocarcinoma of the oesophagus and gastro-oesophageal junction. $\mathrm{Br}$ J Surg. 2017; 104:401-407.

13. Huang J, Yuan Y, Wang Y, Zhang J, Kong W, Chen H, Chen Y, Huang Y. Prognostic value of preoperative plasma fibrinogen level and platelet-to-lymphocyte ratio (F-PLR) in patients with localized upper tract urothelial carcinoma. Oncotarget. 2017; 8:36761-36771. https://doi.org/10.18632/ oncotarget.13611.

14. Fu SJ, Ji F, Han M, Chen MG, Wang XP, Ju WQ, Zhao Q, Wu LW, Ren QQ, Guo ZY, Wang DP, Zhu XF, Ma Y, He XS. Prognostic value of combined preoperative fibrinogen and neutrophil-lymphocyte ratio in patients with hepatocellular carcinoma after liver transplantation. Oncotarget. 2017; 8:4301-4312. https://doi.org/10.18632/oncotarget.13804. 
15. Wakatsuki K, Matsumoto S, Migita K, Ito M, Kunishige T, Nakade H, Nakatani M, Kitano M, Sho M. Preoperative Plasma Fibrinogen is Associated with Lymph Node Metastasis and Predicts Prognosis in Resectable Esophageal Cancer. World J Surg. 2017. https://doi.org/10.1007/ s00268-017-3991-x.

16. Takeuchi H, Ikeuchi S, Kitagawa Y, Shimada A, Oishi T, Isobe Y, Kubochi K, Kitajima M, Matsumoto S. Pretreatment plasma fibrinogen level correlates with tumor progression and metastasis in patients with squamous cell carcinoma of the esophagus. J Gastroenterol Hepatol. 2007; 22:2222-2227.

17. Wang J, Liu H, Shao N, Tan B, Song Q, Jia Y, Cheng Y. The clinical significance of preoperative plasma fibrinogen level and platelet count in resectable esophageal squamous cell carcinoma. World J Surg Oncol. 2015; 13:157.

18. Li XH, Wang XP, Gu WS, Lin JH, Huang H, Kang T, Zhang L, Chen H, Zheng X. Clinical Significance of Preoperative Thrombin Time in Patients with Esophageal Squamous Cell Carcinoma following Surgical Resection. PLoS One. 2015; 10:e0140323.

19. Kijima T, Arigami T, Uchikado Y, Uenosono Y, Kita Y, Owaki T, Mori S, Kurahara H, Kijima Y, Okumura H, Maemura K, Ishigami S, Natsugoe S. Combined fibrinogen and neutrophil-lymphocyte ratio as a prognostic marker of advanced esophageal squamous cell carcinoma. Cancer Sci. 2017; 108:193-199.

20. Zhang SS, Lei YY, Cai XL, Yang H, Xia X, Luo KJ, Su $\mathrm{CH}$, Zou JY, Zeng B, Hu Y, Luo HH. Preoperative serum fibrinogen is an independent prognostic factor in operable esophageal cancer. Oncotarget. 2016; 7:25461-25469. https://doi.org/10.18632/oncotarget.8171.

21. Arigami T, Okumura H, Matsumoto M, Uchikado Y, Uenosono Y, Kita Y, Owaki T, Mori S, Kurahara H, Kijima Y, Ishigami S, Natsugoe S. Analysis of the Fibrinogen and Neutrophil-Lymphocyte Ratio in Esophageal Squamous Cell Carcinoma: A Promising Blood Marker of Tumor Progression and Prognosis. Medicine (Baltimore). 2015; 94:e1702.

22. Suzuki T, Shimada H, Nanami T, Oshima Y, Yajima S, Washizawa N, Kaneko H. Prognostic significance of hyperfibrinogenemia in patients with esophageal squamous cell carcinoma. Int J Clin Oncol. 2017. https://doi. org/10.1007/s10147-016-1087-5.

23. Ilhan-Mutlu A, Starlinger P, Perkmann T, Schoppmann SF, Preusser M, Birner P. Plasma fibrinogen and blood platelet counts are associated with response to neoadjuvant therapy in esophageal cancer. Biomark Med. 2015; 9:327-335.

24. Zhang D, Zhou X, Bao W, Chen Y, Cheng L, Qiu G, Sheng L, Ji Y, Du X. Plasma fibrinogen levels are correlated with postoperative distant metastasis and prognosis in esophageal squamous cell carcinoma. Oncotarget. 2015; 6:38410-38420. https://doi.org/10.18632/oncotarget.4800.

25. Matsuda S, Takeuchi H, Fukuda K, Nakamura R, Takahashi T, Wada N, Kawakubo H, Saikawa Y, Omori T, Kitagawa Y. Clinical significance of plasma fibrinogen level as a predictive marker for postoperative recurrence of esophageal squamous cell carcinoma in patients receiving neoadjuvant treatment. Dis Esophagus. 2014; 27:654-661.

26. Lip GY, Chin BS, Blann AD. Cancer and the prothrombotic state. Lancet Oncol. 2002; 3:27-34

27. Shrihari TG. Dual role of inflammatory mediators in cancer. Ecancermedicalscience. 2017; 11:721.

28. Musolino C, Allegra A, Pioggia G, Gangemi S. Immature myeloid-derived suppressor cells: A bridge between inflammation and cancer. (Review). Oncol Rep. 2017; 37:671-683.

29. Simpson-Haidaris PJ, Rybarczyk B. Tumors and fibrinogen: The role of fibrinogen as an extracellular matrix protein. Ann N Y Acad Sci. 2001; 936:406-425.

30. Sahni A, Khorana AA, Baggs RB, Peng H, Francis CW. FGF-2 binding to fibrin (ogen) is required for augmented angiogenesis. Blood. 2006; 107:126-131.

31. Sahni A, Simpson-Haidaris PJ, Sahni SK, Vaday GG, Francis CW. Fibrinogen synthesized by cancer cells augments the proliferative effect of fibroblast growth factor-2 (FGF-2). J Thromb Haemost. 2008; 6:176-183.

32. Witsch E, Sela M, Yarden Y. Roles for growth factors in cancer progression. Physiology (Bethesda). 2010; 25:85-101.

33. Shu YJ, Weng H, Bao RF, Wu XS, Ding Q, Cao Y, Wang XA, Zhang F, Xiang SS, Li HF, Li ML, Mu JS, Wu WG, Liu YB. Clinical and prognostic significance of preoperative plasma hyperfibrinogenemia in gallbladder cancer patients following surgical resection: a retrospective and in vitro study. BMC Cancer. 2014; 14:566.

34. Steinbrecher KA, Horowitz NA, Blevins EA, Barney KA, Shaw MA, Harmel-Laws E, Finkelman FD, Flick MJ, Pinkerton MD, Talmage KE, Kombrinck KW, Witte DP, Palumbo JS. Colitis-associated cancer is dependent on the interplay between the hemostatic and inflammatory systems and supported by integrin alpha (M) beta(2) engagement of fibrinogen. Cancer Res. 2010; 70:2634-2643.

35. Martino MM, Briquez PS, Ranga A, Lutolf MP, Hubbell JA. Heparin-binding domain of fibrin(ogen) binds growth factors and promotes tissue repair when incorporated within a synthetic matrix. Proc Natl Acad Sci USA. 2013; 110:4563-4568.

36. Staton CA, Brown NJ, Lewis CE. The role of fibrinogen and related fragments in tumour angiogenesis and metastasis. Expert Opin Biol Ther. 2003; 3:1105-1120. 